\title{
Consumer-Feedback Driven- Chain Powers China's E-Commerce
}

\author{
Fuyi Li* \\ University of International Economic Research, China
}

*Corresponding author: Fuyi Li, University of International Business and Economics, China.

Received Date: February 26, 2019

Published Date: March 01, 2019

\section{Introduction}

Recently, the incredible rise of a Chinese e-commerce start-up, Pinduoduo (PDD), has attracted the attention of global capital. PDD, the Shanghai-based social e-commerce company providing daily groceries and home appliances, went public raising $\$ 1.6$ billion in July, which is more expensive than Facebook's IPO and one of the largest deals of the year. Nasdaq evaluated PDD as "it polishes New York's tech IPO crown". Surpassing JD.com and competing against Alibaba, the biggest two e-commerce companies in China, PDD just takes 3 years to crack the highly consolidated China's e-commerce market. How young PDD accomplish this? What's the crucial force lead to the achievement? Is the force a common thing during Chinese e-commerce tycoon's development? [1].

\section{What's the Consumer-Feedback Driven?}

Before the discussion about the reason why PDD successes during such short time, it's necessary to examine how the e-commerce industry in China is organized by taking a look at the dynamics of key actors, and understanding how the value-added processes, namely value chains, in the industry is controlled by the actors and how the power relationship among the actors determine the chains [2].

Generally speaking, the typical power relationship in an industry is either "buyer-driven", which means buyers have absolute dominance, or "producer- drive", signifying producer own governing powers. "Buyer-driven" chains are common in non-durable consumer goods industry, for example, apparel and shoes, with network integration forms, the "buyer" here refers to organizational purchasers like Walmart; while "producer-driven" chains can be observed frequently in natural resources industry, for instance oil and mining, with a vertical integration form. In the China e-commerce era, however, the driving force of the chain is no longer pure "buyer" or "producer", but a more complex concept. Platform companies, Internet-engaged consumers and e-commerce focused producers are the economic roles in the e-commerce value chain, evolving what we call "consumer-feedback driven" chain.

The "consumer-feedback driven" chain shows a brand-new platform integration form. The activities conducted by Internetengaged consumers and e-commerce focused producers both rely on platform companies; the platform works as a bridge bringing together the two actors in high value exchange and enabling vast bilateral interactions. During the exchange and interactions process, consumers' involvement undertakes part value-added activities that was originally assumed by producers, meanwhile, the online individuals get more power via platforms from producers as well as retailers (organizational buyers) and challenge the producers' responsibilities for determining non-production activities, like design, marketing and pricing. For example, on Taobao, which is a subsidiary of Alibaba Group, producers can get a large amount of consumer feedback as ratings and comments about the items sold in real time through online live streaming on social media, which in turns pushes manufacturers to improve the item development and adjust the price. Chinese e-commerce companies, especially those leading platforms as Alibaba, JD.com and PDD focusing on nondurable goods, are not only promoting the emergence of consumerfeedback value chain, but also benefit from the chain [3].

\section{Purchaser's Great Power Determines the PDD's Success}

The mechanism of "consumer-feedback driven" chain determines PDD's quickly rise. PDD's business model is something like a combination of Groupon and Dollar Store, with the characteristic of integrating social media into the online shopping. Prices of items sold on PDD are extreme low once the number of the purchasers in the team qualify for the discounts (sometimes up to $90 \%$ discount), online consumers hence have strong incentives to share product information, through China's dominant social network platform WeChat, to invite their contacts to form a purchase 
group. In order to encourage consumers' active engagements, PDD also provide other motivations such as coupon, free products and cash for product information sharing.

Moreover, PDD targets the price-sensitive people, especially housewives, most of whom live in tier 4 cities and rural areas, had been neglected by JD.com and Alibaba. On WeChat, the major of the contacts are acquaintances or at least the people having similar quality of life, income and consumption habits, therefore the engaged consumers, in fact, do a very precise marketing for the producers. Through the information sharing, the producers easily get an enormous amount of customer information and huge orders, more importantly, with nearly no any marketing and advertising cost. The effect of Economies of Scale also facilitates producers lower the cost. The larger the production scale, the lower the per unit product cost. Hence, they are able to accept price cut. In this sense, purchasers' feedback influences the production activities along the value chain. As aforementioned, Internet-engaged consumers take away some powers, marketing and advertising here, from e-commerce focused producers. As for PDD, an e-commerce platform, its chief assets are traffic and interaction, the more users (producers and consumers) and interaction it has, the more competitive and successful it is.

\section{The Common Mechanism Underlying Chinese Platform's Rise}

Besides PDD, Alibaba and JD.com are also typical examples of the platforms reshaping the power relationships between the different actors in the chain. Take Taobao as an example, the apparel brands, especially small and media enterprises, work with online celebrities on the social media platform WeBo, a Chinese Facebook, to attract the customers. The original equipment manufacturer apparel plants make samples for the online celebrities, who then post photos of themselves in the garments on social media. The online celebrities' direct followers on WeBo to the online store. The producers adjust the garment design and production according to the followers' feedback.

In this way, the engaged customers on the platform are capable of entering into some value added activities, promoting producers' end market upgrading and function upgrading; the e-commerce focused producers on the platforms accumulate a mass of crucial business information generated by the network including consumer preferences and online activities with low cost and threshold, attracting further more consumers; the e-commerce platform create more value and become more competitive with the more interactions the consumers and producers have. In a simple terms, consumers and platforms currently share the cake which exclusively belongs to supply side, in the meantime, the cake itself becomes far larger than before owning to platforms. Obviously, the far-reaching reshape of relationship provides multilateral benefits to consumers, producers and platforms, contributing to China's flourishing e-commerce industry.

\section{Government's Role in the Reshape}

The evolve of "consumer-feedback driven" chain in China's e-commerce industry is inseparable from the dual roles of entrepreneurship and a favorable condition created by Chinese government. The concrete supportive measures include increasing Internet access, facilitating the online payment and promoting the delivery system. For example, a total of $\$ 182$ billion has been invested in improving and constructing fiber-optic and $4 \mathrm{G}$ networks since 2015; the China's central bank built a new clearinghouse for the non-bank payment to achieve an easy and safety online payment. In the establishment of a favorable macro environment, China act as state developmentalism; in the encouraging e-commerce industry to develop freely, Chinese governments adopt a Neo-liberal attitude. This might be a worthy lesson China provide to other economics. But there is a still warning case, during the early development stage of Chinese e-commerce companies, they all face lots of charges for the fake and counterfeits, just like today's PDD, which severely pressure the sustainable growth of the industry. On this view, government needs to do a material job in balancing supervision reinforces and maintaining free e-commerce market.

\section{Acknowledgement}

None.

\section{Conflict of Interest}

No conflict of interest.

\section{References}

1. Li F, Frederick S, Gereffi G (2018) E-commerce and industrial upgrading in the Chinese apparel value chain. Journal of Contemporary Asia.

2. Gereffi G (2009) Beyond the producer-driven/ buyer-driven dichotomy: the evolution of global value chains in the internet era. IDS Bulletin 32(3): 30-40.

3. Van Alstyne MW, Parker GG, Choudary SP (2016) Pipelines, platforms, and the new rules of strategy. Harvard Business Review. 